\title{
Influence of body mass, food concentration, temperature and filtering activity on the oxygen uptake of the appendicularian Oikopleura dioica
}

\author{
Fabien Lombard ${ }^{*}$, Antoine Sciandra, Gabriel Gorsky \\ LOV, CNRS/UPMC, UMR 9073, Observatoire Océanologique, BP 28, 06234 Villefranche-sur-Mer, France
}

\begin{abstract}
In appendicularians, filtering activity is known to vary inversely with food concentration. Here, we investigate the response of respiration rate to clearance rate (notably tail beating), which is minimum in anesthetized animals and maximum in conditions of food deprivation. Respiration of different size classes of the appendicularian Oikopleura dioica was measured at $15^{\circ} \mathrm{C}$ in 4 contrasting situations: in (1) high (H) and (2) low (L) concentrations of a lyophilized mixture of Isochrysis galbana (haptophyceae), with Thalassiosira pseudonana (diatom) offered as food, (3) without food and (4) in the presence of an anaesthetic. Measurements of the oxygen consumption in H concentration were repeated at $22^{\circ} \mathrm{C}$ to examine the effect of temperature on respiration. The weight-specific respiration measured in $\mathrm{H}, \mathrm{L}$, and no food conditions were not significantly different. The absence of an apparent relationship between the activities of filtration and respiration may be explained by the unusual high basal oxygen consumption measured in anaesthetized appendicularians $(67 \%$ of the total respiration rate of active animals). Our results also suggest that the respiration rate of $O$. dioica was overestimated in past studies (1.6 to 2.0 times). Despite this, the respiration of $O$. dioica measured in this study is generally higher than the rates reported for other zooplankton species. The $Q_{10}$ determined from the temperature-dependent oxygen consumption (2.3) was close to the earlier observations.
\end{abstract}

KEY WORDS: Appendicularians - Oxygen consumption - Basal respiration - Food-dependent respiration $\cdot$ Temperature-dependent respiration $\cdot Q_{10} \cdot$ Oikopleura dioica

\section{INTRODUCTION}

Appendicularians (tunicates) are an important component of the marine food web (Gorsky \& Fenaux 1998). Their high specific growth and filtration rates (Deibel 1998, Hopcroft et al. 1998) allow them to rapidly clear large volumes of seawater. They live in spherical mucous houses which concentrate food particles from ambient water (Flood \& Deibel 1998). Appendicularian tail beating induces water circulation through the house (Flood \& Deibel 1998) and the feeding filters retain particles between 0.2 and $30 \mu \mathrm{m}$ with variable efficiency (Fernández et al. 2004). Due to their feeding behaviour, appendicularians bypass the classical food web and directly transfer the micron-sized particles to higher trophic levels such as small pelagic zooplankton or fishes (Gorsky \& Fenaux 1998, Purcell et al. 2004). Appendicularians can form dense blooms (Hopcroft \& Roff 1995, Uye \& Ichino 1995) resulting from potentially very high growth rates, notably in warm waters. One appendicularian can produce up to 19 houses per day (Oikopleura dioica at $25^{\circ} \mathrm{C}_{i}$ Sato et al. 2001). The discarded houses, enriched by the trapped particulate matter contribute significantly to the carbon export to deeper oceanic waters (Gorsky \& Fenaux 1998, Alldredge 2004, Maar et al. 2004).

The cosmopolitan species Oikopleura dioica used in this work can be found from the Caribbean (Hopcroft et al. 1998) to Sweden (Maar et al. 2004). Being relatively easy to grow under controlled laboratory 
conditions (Fenaux \& Gorsky 1985), this species is the most studied of the appendicularians. However, little is known about its physiology and in particular its response to different food levels. The response of individual growth to different trophic regimes is related to food utilization (filtration, ingestion and assimilation) and energy losses (house secretion, respiration). Thus, all these processes need to be quantified within complementary experiments to obtain a unified understanding of the biology of $O$. dioica.

Filtration rate, the most studied physiological process in appendicularians, has been estimated for different temperatures (Paffenhöfer 1976, Gorsky 1980, King et al. 1980, Broms \& Tiselius 2003), food concentrations (Selander \& Tiselius 2003), and particle size (Fernández et al. 2004). The filtration rate was related to appendicularian size, temperature, concentration, and nature of the food particles. Ingestion was measured for different algal species at various concentrations (Acuña \& Kiefer 2000), as well as the gut residence time (López-Urrutia \& Acuña 1999), and seemed to depend on the food concentration. Sato et al. (2001) studied the effects of temperature, algal concentration, and salinities on the production of houses. The latter was mainly dependent on the experimental temperature.

The only experimental studies specifically devoted to the measurement of oxygen consumption by appendicularians were those performed by Gorsky (1980), Gorsky et al. (1984) and Gorsky et al. (1987); they examined different temperatures and body sizes. Surprisingly, there was, to our knowledge, no attempt to clarify the relationship between food level and respiration rate. Respiration studies performed with copepods (Nival et al. 1972, Mayzaud 1973a, Ikeda 1977, Abou Debs 1984), and large gelatinous species (Kremer 1982), revealed that, in most cases, starvation or low food concentration tend to reduce their respiration activity (Ikeda 1977). The extrapolation to appendicularians may be open to question since Oikopleura dioica responds to food deprivation by increasing its feeding activity, in particular the frequency of its tail beating (Selander \& Tiselius 2003) that in turn should increase the respiration.

In their growth models, Touratier et al. (2003) and López-Urrutia et al. (2003) proposed different hypotheses to formalize the respiration process, which are not completely satisfactory. Touratier et al. (2003) parameterized their model using the hypothesis that all the assimilated energy not allocated for growth is respired, with a coefficient of net growth efficiency derived from a copepod growth model (Touratier et al. 1999). Ultimately, this formalization leads one to consider that respiration is related to food concentration, although this effect was never proven for appendicularians. On the other hand, López-Urrutia et al. (2003), by using a constant respiration rate, simply considered that no relationship exists between respiration and growth and, by extension, between respiration and food concentration.

In order to understand and model a more realistic growth budget of Oikopleura dioica, the basal respiration, the relationships between food concentration and the respiration as a function of size and temperature have to be determined within controlled-condition experiments. To complement the study of Gorsky et al. (1987), relating the effect of body size on oxygen consumption, a first experiment was conducted to measure the oxygen consumption during the development of 1 appendicularian cohort fed at 2 different food concentrations. This experiment was also designed to test the hypothesis proposed by Touratier et al. (2003) that the respiration of Oikopleura dioica may be related to the available food concentration. A second experiment was conducted to determine the difference in oxygen consumption between starved and anaesthetized appendicularians which corresponds to maximum filtration activity (Acuña \& Kiefer 2000, Selander \& Tiselius 2003) and basal respiration activity respectively. The third experiment was performed to parameterize the effect of temperature on respiration in optimal food conditions.

\section{MATERIALS AND METHODS}

Maintenance of appendicularians and algae cultures. Although usually abundant in the North Ligurian Sea, Oikopleura dioica has been quasi absent from this area since 1998. Laboratory cultures were therefore initiated with $O$. dioica originating from the Sars International Centre for Marine Molecular Biology in Bergen (Norway), where permanent breeding of this species is maintained throughout the year. Fertilised eggs were transported from Bergen to Villefranche-sur-Mer by overnight mail in $200 \mathrm{ml}$ plastic cell culture flasks. Upon their arrival, embryos were progressively placed in new fresh seawater to attenuate the environmental stress (salinity, temperature). Mass culture and experiments were conducted in a $15 \pm 1^{\circ} \mathrm{C}$ temperature-controlled room. Appendicularians were routinely cultured in 2, 5 or 201 polycarbonate beakers. Plastic paddles were rotated at $10 \mathrm{rpm}$ (Fenaux \& Gorsky 1985) to homogenise the cultures. Each day, half of the culture volume was replaced with $20 \mu \mathrm{m}$ filtered surface seawater from the Villefranche bay, and mature animals were selected and transferred into a $2 \mathrm{l}$ beaker of fresh seawater for spawning. Axenic cultures of Isochrisis galbana (haptophyceae, 4 to $5 \mu \mathrm{m}$ equivalent spherical diameter, ESD) and 
Thalassiosira pseudonana (diatom, 5 to $6 \mu \mathrm{m}$ ESD) grown at $20^{\circ} \mathrm{C}$ with sterile $\mathrm{F} / 2$ medium (Sigma) under $200 \mu \mathrm{mol}$ quanta $\mathrm{m}^{-2} \mathrm{sec}^{-1}$ light intensity, were added to maintain an optimal food concentration of approximately 10000 cells ml-1 (Gorsky 1980). The food concentration was monitored with a particle counter (Coulter Multisizer II).

Experimental design. Expt 1: The respiration rate was measured daily on 2 populations originating from a single synchronized spawn, and respectively kept at high $(\mathrm{H})$ and low (L) food concentrations (see below). Fertilisation was set up with 45 to 55 mature females and 25 to 35 mature males in a 21 beaker. Spawning was synchronized through gentle mixing. Just after the production of the first houses, the cohort was split up into 2 identical populations subsequently submitted to $\mathrm{H}$ and $\mathrm{L}$ food regimes. On Day 1, the volume of each culture was augmented from 1 to 51 with fresh seawater, and the food concentrations adjusted accordingly. On Day 2, cultures were split into 2 duplicates ( $2 \mathrm{H}$ and $2 \mathrm{~L}$ ) and the volume adjusted again to 51 with fresh seawater. From Days 3 to 5, appendicularians which were not used for the incubation experiments were transferred with a wide bore pipette into new 51 beakers of fresh seawater with the appropriate food regime.

$\mathrm{H}$ and $\mathrm{L}$ food concentrations were representative, in term of biomass, of mesotrophic and oligotrophic conditions. From Days 1 to 3, the $\mathrm{H}$ food regime was obtained by adjusting the concentrations of both Isochrisis galbana and Thalassiosira pseudonana to 2000 cells $\mathrm{ml}^{-1}$ in the appendicularian cultures. After Day 3, these concentrations were doubled. The L food regime was 6 -fold lower than the $\mathrm{H}$ food concentration.

Each day, a known number of appendicularians were sampled in the breeding beakers and prepared for respiration incubations. In order to limit the bias due to the respiration of algae and bacteria living in faecal pellets and in the houses, appendicularians were forced to leave their houses and placed in $0.2 \mu \mathrm{m}$ filtered seawater for $10 \mathrm{~min}$. Then, animals with a new house and empty (transparent) stomach were transferred for incubation into autoclaved $25 \mathrm{ml}$ glass bottles filled with $\mathrm{O}_{2}$-saturated, $0.2 \mu \mathrm{m}$ filtered seawater. Bacteria-free lyophilised algae were used during incubation to feed the appendicularians in $\mathrm{H}$ or $\mathrm{L}$ food concentrations. Cultures of Isochrisis galbana and Thalassiosira pseudonana were concentrated by soft centrifugation $(500 \times g$ for $15 \mathrm{~min})$ and lyophilised for $12 \mathrm{~h}\left(-40^{\circ} \mathrm{C}, 0.4 \mathrm{mbar}\right.$, VirTis Bench Top 3 Model $)$. Control experiments showed that the oxygen consumption remained the same in filtered seawater with $\left(0.019 \pm 0.009 \mu \mathrm{O}_{2} \mathrm{ml}^{-1} \mathrm{~h}^{-1} ; \mathrm{n}=21\right)$ or without $(0.018 \pm$ $0.002 \mu \mathrm{O}_{2} \mathrm{ml}^{-1} \mathrm{~h}^{-1} ; \mathrm{n}=42$ ) lyophilised algae, and that such a lyophilised diet allowed Oikopleura dioica to grow during $7 \mathrm{~d}$ at a rate similar to that obtained when fed with fresh algae. According to this protocol, respiration in this experiment was measured in duplicates from Days 2 to 4, and in triplicates on Day 5, in both the $\mathrm{H}$ and $\mathrm{L}$ food regimes. Nine control bottles without appendicularians were prepared. Three were filled with seawater only, 3 with $\mathrm{H}$ and 3 with L food concentrations.

Fifty individuals from Days 1 to 3, 30 on Day 4, and 20 on Day 5 were placed in the incubation bottles. Experimental and control bottles were hermetically closed, kept in the dark with wrapped aluminium foil, and placed on an agitator rotating at $8 \mathrm{rpm}$. The duration of incubations was $12 \mathrm{~h}$, and bottles with air bubbles or dead appendicularians were discarded.

At the end of the incubation period, experimental and control bottles were sampled with a syringe, and oxygen concentration was measured with a polarographic oxygen meter (Strathkelvin Instrument, Model 781 fitted with a Clark electrode). Body and gonad lengths of Oikopleura dioica were measured with a micrometer mounted on a stereomicroscope. Body length was converted into carbon weight using the relationship from King et al. (1980). This overall experiment was conducted twice.

Expt 2: This experiment was conducted on large appendicularians (>500 $\mu \mathrm{m}$ length) originated from a synchronized culture (as described above). Following the same incubation protocol, oxygen consumption of Oikopleura dioica was measured under 2 experimental conditions. In the first one, animals were placed in $0.2 \mu \mathrm{m}$ filtered seawater to increase the tail beat frequency as described by Selander \& Tiselius (2003) and thus the oxygen consumption; in the second one, appendicularians were placed in fresh filtered seawater and anaesthetized with tricaine methanesulfonate (Sandoz MS-222). Commonly used in fisheries as an anaesthetic, MS-222 is known to suppress motor activity. Only the respiration derived from muscular movement is affected among fishes (Leonard et al. 1999), whereas MS-222 does not affect cutaneous respiration. For appendicularians, MS-222 does not affect the vital activities: spiracles and heart continue to function normally (authors' pers. obs.). Thus, since motor activity and digestion are inhibited, MS-222 permits estimation of the basal respiration of motionless appendicularians. Test experiments showed no difference in oxygen consumption between seawater with $\left(0.015 \pm 0.006 \mu \mathrm{lO}_{2} \mathrm{ml}^{-1} \mathrm{~h}^{-1} ; \mathrm{n}=12\right)$ and without $\left(0.018 \pm 0.002 \mu \mathrm{l} \mathrm{O}_{2} \mathrm{ml}^{-1} \mathrm{~h}^{-1} ; \mathrm{n}=12\right) \mathrm{MS}-222$.

Preliminary tests were conducted to determine the optimal incubation time for accurate respiration measurements and for stress limitation of organisms. These tests showed that $90 \%$ of an appendicularian population transferred into $0.2 \mu \mathrm{m}$ filtered seawater with a 
new and clean house were still alive $6 \mathrm{~h}$ later, and that $50 \%$ of them were still occupying their house. We decided to set the incubation time to 4 to $5 \mathrm{~h}$ with a sufficient number (5 to 25) of large individuals. Under both conditions (no food and anaesthetised), the oxygen concentration in experimental and control bottles was measured in triplicates.

Expt 3: In order to test the influence of temperature on respiration, oxygen consumption was measured on appendicularians cultivated as above but at $22^{\circ} \mathrm{C}$. The incubation time was shorter $(2 \mathrm{~h})$ with an $\mathrm{H}$ concentration of lyophilized algae and we used relatively large appendicularians (500 to $900 \mu \mathrm{m}$ trunk length) in order to have accurate estimations of oxygen variation. Incubations with and without animals (controls) were performed in triplicates.

Respiration function. According to Moloney \& Field (1989) the different metabolic rates in animals follow a general allometric law which can be applied to respiration:

$$
R=r \times Q_{1}^{T} \times W^{b}
$$

where $R\left(\mu l \mathrm{O}_{2}\right.$ ind $\left.^{-1} \mathrm{~h}^{-1}\right)$ is oxygen consumption, $W$ is body weight $\left(\mu \mathrm{gC}\right.$ ind $\left.^{-1}\right), b$ a scaling parameter, $r$ $\left(\mu \mathrm{O}_{2} \mu \mathrm{g} \mathrm{C}^{-1} \mathrm{~h}^{-1}\right)$ the specific respiration rate at $0^{\circ} \mathrm{C}, T$ $\left({ }^{\circ} \mathrm{C}\right)$ the temperature and $Q_{1}$ the 10 th root of the $Q_{10}$ coefficient.

Since $r, Q_{1}$ and $b$ are supposed to be species-specific and thus constants we can, at a given temperature, fit a power relationship to our data:

$$
R=a \times W^{b}
$$

where $a$ is the temperature-dependent metabolic rate. Two metabolic rates $a_{1}$ and $a_{2}$ were measured at 2 temperatures $T_{1}\left(15^{\circ} \mathrm{C}\right)$ and $T_{2}\left(22^{\circ} \mathrm{C}\right)$. The $Q_{1}$ coefficient was then calculated using Eqs. (1) \& (2):

$$
Q_{1}=\left(\frac{a_{1}}{a_{2}}\right)^{\frac{1}{T_{1}-T_{2}}}
$$

\section{RESULTS}

Four days after fertilization, the individual respiration rate at $15^{\circ} \mathrm{C}$ was significantly higher in the $\mathrm{H}$ (Fig. 1a) than in the L food conditions ( $t$-test, Day $4: \mathrm{p}=$ $0.028, \mathrm{n}=4$; Day 5: $\mathrm{p}=0.095, \mathrm{n}=6$ ). Similarly, bodies and gonads of individuals fed with more food reached higher sizes at the same time ( $t$-test, Day 4: $\mathrm{p}=0.087$, $\mathrm{n}=4$; Day 5: $\mathrm{p}=0.033, \mathrm{n}=6$ ). At the end of the experiment, the mean body size was $26 \%$ higher in the $\mathrm{H}(815 \pm 51 \mu \mathrm{m})$ compared to the $\mathrm{L}$ food regime $(665 \pm$ $43 \mu \mathrm{m})$ (Fig. 1b). In most cases, the growth rate calculated from the daily variation of individual carbon weight was higher in the $\mathrm{H}$ concentration, and fol-
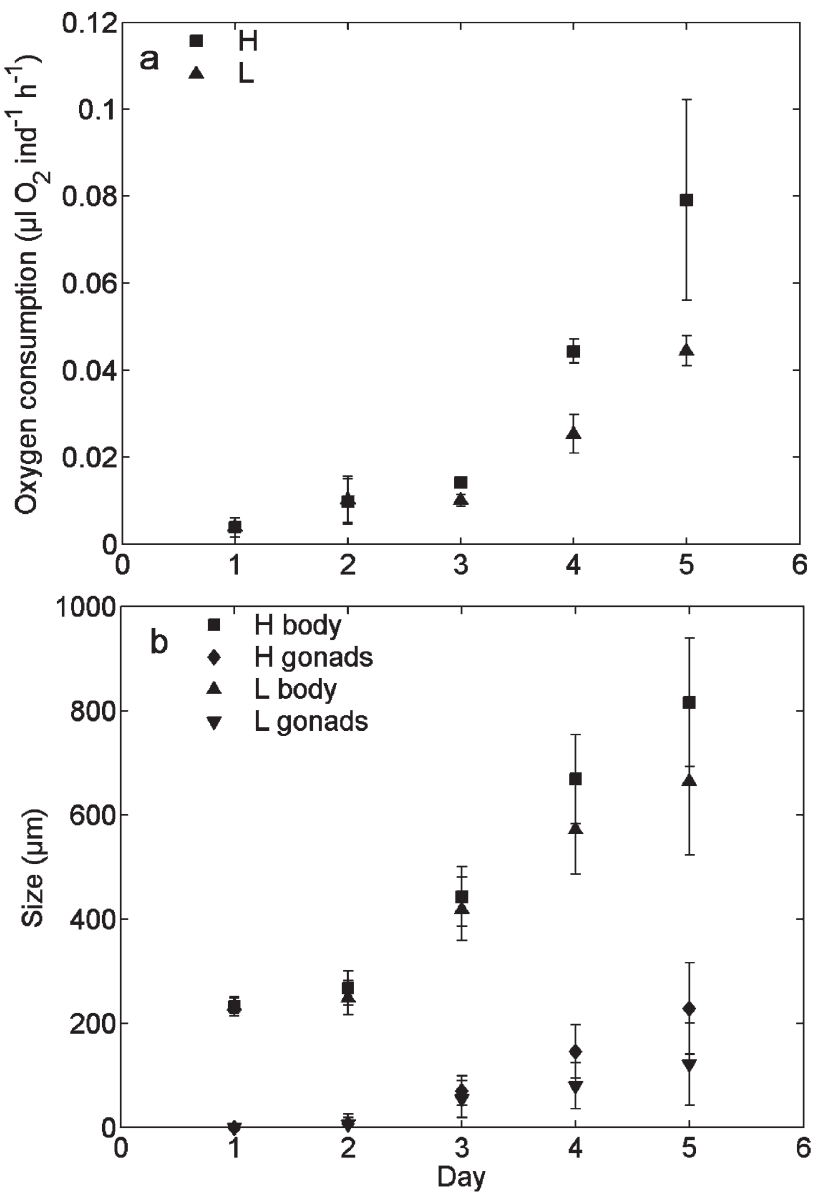

Fig. 1. Oikopleura dioica. (a) Mean oxygen consumption $\left(\mu \mathrm{O}_{2}\right.$ ind $\left.^{-1} \mathrm{~h}^{-1}\right)$ from Day 1 after fertilization to Day 5 fed with $\mathrm{H}$ (high food concentration) and L (low food concentration) conditions. Verticals bars denote the standard deviation. (b) $O$. dioica mean body size $(\mu \mathrm{m})$ for $\mathrm{H}$ and $\mathrm{L}$ food concentration and mean gonad size for $\mathrm{H}$ and $\mathrm{L}$ food concentration. Verticals bars denote the standard deviation

lowed a logistic tendency for the 2 trophic conditions, i.e. with low value $\left(0.21\right.$ to $\left.0.37 \mathrm{~d}^{-1}\right)$ the first day, maximum values (1.33 to $1.35 \mathrm{~d}^{-1}$ ) between Days 2 and 3 , and reduced values afterwards $\left(0.40\right.$ to $\left.1.08 \mathrm{~d}^{-1}\right)$.

When plotted against individual weights, the respiration rates measured at $\mathrm{H}, \mathrm{L}$, and no food conditions (at $15^{\circ} \mathrm{C}$ ) were very similar (Fig. 2). This suggests that the difference in respiration was ultimately driven by the appendicularian size variation and not by the available food concentration. For these 3 experimental conditions, an appendicularian of $4 \mu \mathrm{g} C$ respired approximately $0.11 \mu \mathrm{O}_{2} \mathrm{~h}^{-1}$ and on log-transformed data, the regression intercepts $\left(\log r+T \log Q_{1}\right)$ and the slope $(b)$ were not significantly different (covariance analysis $F_{2,49}=3.16, \mathrm{p}>0.05 ; F_{2,49}=0.48, \mathrm{p}>0.05$ respectively).

At $15^{\circ} \mathrm{C}$, anesthetized appendicularians consumed $33 \%$ less oxygen $\left(0.06 \mu \mathrm{O} \mathrm{O}_{2}\right.$ ind. $^{-1} \mathrm{~h}^{-1}$ for a $4 \mu \mathrm{g} \mathrm{C}$ body mass appendicularian) than the active ones (Fig. 2). On 


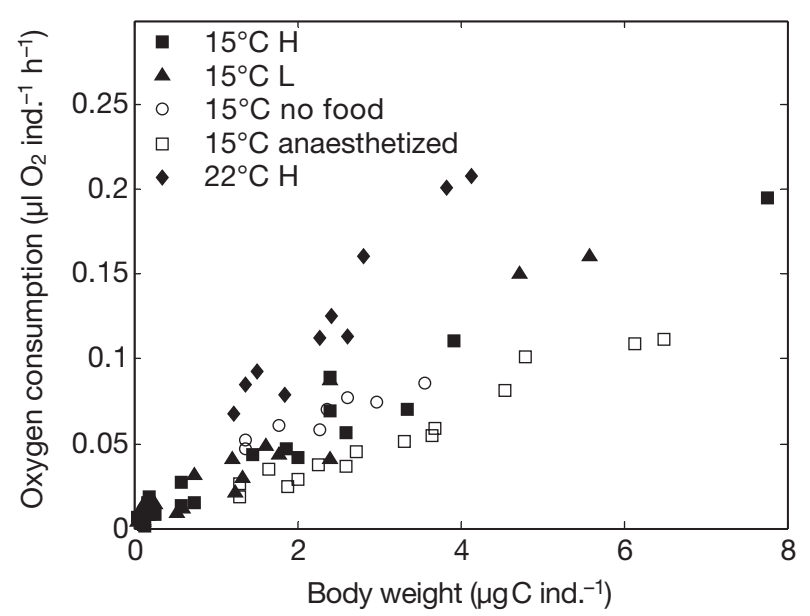

Fig. 2. Oikopleura dioica. Relationship between carbon body weight $\left(\mu \mathrm{g} \mathrm{C}\right.$ ind.$\left.^{-1}\right)$ and respiration $\left(\mu l \mathrm{O}_{2}\right.$ ind $\left.^{-1} \mathrm{~h}^{-1}\right)$ when incubated at $15^{\circ} \mathrm{C}$ with $\mathrm{H}$ (high food concentration), L (low food concentration), no food, and anaesthetic; and at $22^{\circ} \mathrm{C}$ with $\mathrm{H}$ food regime. Carbon body weight was obtained from body length using the relationship from King et al. (1980)

log-transformed data, the slope of the respiration versus body size relationship was similar for animals with or without anaesthetics (covariance analysis $F_{3,63}=$ 0.78, p > 0.05), with an allometric coefficient, $b$, approximately equal to 0.75 (Table 1 ), the intercept however was significantly different (covariance analysis $\left.F_{3,63}=5.30, \mathrm{p}<0.05\right)$.

For a given size, the oxygen consumption of normally fed appendicularians was systematically higher at $22^{\circ} \mathrm{C}\left(0.2 \mu \mathrm{Ol}_{2}\right.$ ind. $^{-1} \mathrm{~h}^{-1}$ for a $4 \mu \mathrm{g} \mathrm{C}$ body mass appendicularian) than at $15^{\circ} \mathrm{C}$. The $22^{\circ} \mathrm{C}$ experiments had significantly different intercepts than the experiments conducted at $15^{\circ} \mathrm{C}$ (covariance analysis $F_{3,59}=$ 24.56, p < 0.05) but had similar slopes (covariance analysis $\left.F_{3,59}=0.51, \mathrm{p}>0.05\right)$. Therefore, oxygen consumption-body weight relationships can be considered similar for $\mathrm{H}, \mathrm{L}$, and for no food conditions (Fig. 3). The difference between the experiments at

Table 1. Parameters of the allometric relationship between oxygen consumption $\left(R, \mu \mathrm{O}_{2}\right.$ ind $\left.^{-1} \mathrm{~h}^{-1}\right)$ and appendicularian weight $(W, \mu \mathrm{C})$. The form $R=a W^{b}$ was used when only 1 experimental temperature was present and the form $R=$ $a Q_{1}{ }^{T} W^{b}$ was used between $15^{\circ} \mathrm{C}$ (high [H], low [L] and no food conditions) and $22^{\circ} \mathrm{C}$ when calculation of the $Q_{10}$ parameter was possible

\begin{tabular}{|lcccccc|}
\hline Expt & $a$ & $b$ & $Q_{10}$ & $Q_{1}$ & $\mathrm{r}^{2}$ & $\mathrm{n}$ \\
\hline $\mathrm{H} 15^{\circ} \mathrm{C}$ & $0.028 \pm 0.002$ & $0.73 \pm 0.05$ & & & 0.81 & 23 \\
$\mathrm{~L} 15^{\circ} \mathrm{C}$ & $0.024 \pm 0.003$ & $0.62 \pm 0.06$ & & & 0.85 & 23 \\
No food $15^{\circ} \mathrm{C}$ & $0.042 \pm 0.003$ & $0.57 \pm 0.08$ & & & 0.89 & 8 \\
Anaesthetized $15^{\circ} \mathrm{C}$ & $0.016 \pm 0.001$ & $1.05 \pm 0.08$ & & & 0.93 & 15 \\
$\mathrm{H} 22^{\circ} \mathrm{C}$ & $0.057 \pm 0.005$ & $0.89 \pm 0.10$ & & & 0.91 & 10 \\
$\mathrm{H}+\mathrm{L}+$ No food $15^{\circ} \mathrm{C}$ & $0.032 \pm 0.002$ & $0.75 \pm 0.04$ & & & 0.85 & 54 \\
Pooled data & 0.011 & 0.75 & 2.30 & 1.09 & & \\
\hline
\end{tabular}

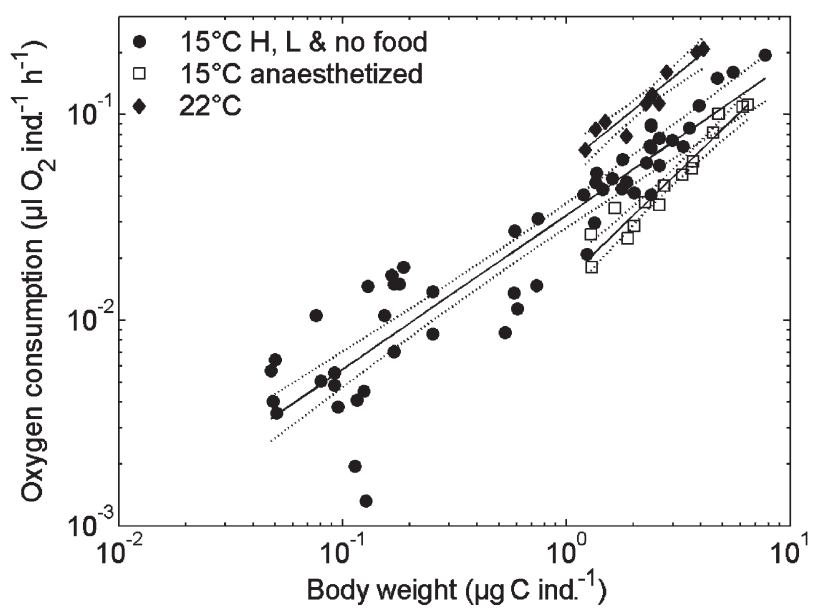

Fig. 3. Oikopleura dioica. Relationship between carbon body weight ( $\mu \mathrm{g} \mathrm{C}$ ind. ${ }^{-1}$ ) and oxygen consumption $\left(\mu l \mathrm{O}_{2}\right.$ ind. $\left.{ }^{-1} \mathrm{~h}^{-1}\right)$ for active $\mathrm{O}$. dioica at $15^{\circ} \mathrm{C}$, and $22^{\circ} \mathrm{C}$ and for anaesthetized appendicularians at $15^{\circ} \mathrm{C}_{\text {; }}$ continuous lines: least-square regressions for data fitted with a power model; dotted lines: $95 \%$ confidence intervals for power regressions. Relationships for $\mathrm{H}$ (high food), L (low food) and no food conditions at $15^{\circ} \mathrm{C}$ were not significantly different and were pooled. The coefficients of the power regressions between oxygen consumption $\left(R, \mu \mathrm{O}_{2}\right.$ ind. $\left.^{-1} \mathrm{~h}^{-1}\right)$ and body weight $\left(W, \mu \mathrm{g} \mathrm{C}\right.$ ind..$\left.^{-1}\right)$ are listed in Table 1

15 and at $22^{\circ} \mathrm{C}$ allows us to estimate a $Q_{1}$ coefficient of approximately 1.09 , corresponding to a $Q_{10}$ of 2.3 . The calculated specific respiration rate at $0^{\circ} \mathrm{C}(r)$ is $0.011 \mu \mathrm{O}_{2} \mu \mathrm{g} \mathrm{C}^{-1} \mathrm{~h}^{-1}$ (Table 1).

\section{DISCUSSION}

The comparison of the respiration rates measured in this work with those measured in previous studies indicates that results are sensitive to experimental protocols, and that previous respiration rates of appendicularians were sometimes overestimated. For example, the respiration rates of Oikopleura dioica determined at the same temperature by Gorsky (1980) and Gorsky et al. (1987) were respectively 2.03 and 1.62 times higher than in the present study. Because appendicularians are relatively small (100 to $1500 \mu \mathrm{m}$ trunk length) and contain low levels of metabolic reserves (Deibel 1998), the determination of their respiration rates requires rather long incubation times during which food is provided to avoid mortality. In these conditions, the background respiration due to free or stomach-accumulated phytoplanktonic cells 
is enhanced by appendicularian excretion and by the activity of bacteria developing on faecal pellets. It has been shown that the amount of algae retained in the appendicularian stomach can be important (LópezUrrutia \& Acuña 1999), and that digestion is often incomplete (Gorsky 1980, Gorsky et al. 1999). Presumably, the incubation time, the food concentration, the use of non-autoclaved vials, and the incomplete emptying of the digestive tract prior to the incubations may explain the higher values obtained by Gorsky (1980) and Gorsky et al. (1987). In order to reduce as far as possible these biases, seawater was pre-filtered at $0.2 \mu \mathrm{m}$, incubation bottles were rinsed with acid and autoclaved, incubation time was shortened, and only appendicularians in new houses with empty stomachs were incubated in the present study. The use of lyophilized algae allowed adequate feeding of the appendicularians during incubations while preventing phytoplankton respiration.

Although not statistically different, the weightspecific exponent $b$ obtained for the various experimental conditions presents some variability. For the different food regimes at $15^{\circ} \mathrm{C}$, it varies from 0.57 to 0.75 , and increases respectively to 0.89 and 1.05 , at $22^{\circ} \mathrm{C}$ and for anesthetized animals at $15^{\circ} \mathrm{C}$. These differences are essentially due to the fact that the size range of Oikopleura dioica individuals used during incubations was relatively narrow. This coefficient has been shown to vary in relation to the nutritional status (Barnes \& Barnes 1969), temperature (Conover 1960, Ikeda 1974, Ivleva 1980), and salinity (Milliou \& Moraitou-Apostolopoulou 1991). For O. dioica, the precision of our measurements do not allow us to detect significant differences between the different experi- mental conditions tested, and we thus consider that the mean value of 0.75 applies to all of them. This value falls in the range previously determined for appendicularians: for O. dioica 0.72 (Gorsky 1980), and 0.61 to 0.72 (Gorsky et al. 1987) and for O. longicauda 0.87 (Gorsky et al. 1984).

According to the mean $b$ value of 0.75 determined in our experiments, which is similar to that given by Hemmingsen (1960) for poikilotherms, the slope of the appendicularian respiration versus size relationship is closer to the crustaceans than to the gelatinous zooplankton. A $b$ value of 0.77 was determined for $E u$ phausia pacifica (Table 2) at 8 and $12^{\circ} \mathrm{C}$ (Ross 1982), and $0.75,0.84$ and 0.82 (Table 3 ) were determined for different copepod species (Nival et al. 1972, Vidal 1980). A very low value of 0.45 was also measured for some euphausid species such as Meganictyphanes norvegica (Mayzaud 1973a). Gelatinous zooplankton are most often characterized by a higher weight-specific exponent averaging 1.0 to 1.05 for salps (Cetta et al. 1986, Biggs 1977), 0.9 to 0.98 for epipelagic ctenophores (Kremer et al. 1986, Svetlichny et al. 2004), between 0.98 and 1.02 for deep sea ctenophores (Youngbluth et al. 1988) and 1.26 for some hydromedusa (Biggs 1977).

The temperature effect on a specific physiological activity, such as respiration, filtration, digestion and others, is generally quantified through the convenient $Q_{10}$ expression, even if other formulations exist (see Ivleva 1980). For Oikopleura dioica, a respiration $Q_{10}$ of 2.30 was determined in the 15 to $22^{\circ} \mathrm{C}$ range, which is very close to the value of 2.25 found by Gorsky et al. (1987) between 15 and $24^{\circ} \mathrm{C}$ for the same species (Table 3). It is worth noting that the $Q_{10}$ determination depends on the temperature range for which it has

Table 2. Relationship between respiration $\left(R, \mu \mathrm{O} \mathrm{O}_{2}\right.$ ind $\left.^{-1} \mathrm{~h}^{-1}\right)$ and body weight $\left(W, \mu \mathrm{g} \mathrm{C}\right.$ ind. $\left.{ }^{-1}\right)$ for different zooplankton groups. The form $R=a W^{b}$ was used when data for only 1 temperature was available and $R=a Q_{1}{ }^{T} W^{b}$ was used when $Q_{10}$ could be calculated

\begin{tabular}{|c|c|c|c|c|c|c|}
\hline Source & Species & $T\left({ }^{\circ} \mathrm{C}\right)$ & a & $b$ & $Q_{10}$ & $Q_{1}$ \\
\hline Cetta et al. $(1986)^{a}$ & $\begin{array}{l}\text { Salpa fusiformis chain } \\
\text { Salpa fusiformis solitary }\end{array}$ & $\begin{array}{l}13-19 \\
13-19\end{array}$ & $\begin{array}{l}0.087 \\
0.006\end{array}$ & $\begin{array}{l}0.68 \\
1.15\end{array}$ & & \\
\hline $\operatorname{Ross}(1982)^{a}$ & Euphausia pacifica & $\begin{array}{c}8 \\
12 \\
8-12\end{array}$ & $\begin{array}{l}0.008 \\
0.010 \\
0.004\end{array}$ & $\begin{array}{l}0.77 \\
0.77 \\
0.77\end{array}$ & 2.03 & 1.07 \\
\hline Gorsky $(1980)^{a}$ & Oikopleura dioica & $\begin{array}{c}15 \\
23 \\
15-23\end{array}$ & $\begin{array}{l}0.081 \\
0.175 \\
0.019\end{array}$ & $\begin{array}{l}0.80 \\
0.34 \\
0.72\end{array}$ & 2.62 & 1.10 \\
\hline Gorsky et al. (1984) & Oikopleura longicauda & 20 & 0.192 & 0.87 & & \\
\hline $\begin{array}{l}\text { Gorsky et al. }(1987)^{\mathrm{a}} \\
\text { calculated from } \\
\text { data points }\end{array}$ & Oikopleura dioica & $\begin{array}{c}15 \\
20 \\
24 \\
15-20 \\
20-24 \\
15-24\end{array}$ & $\begin{array}{l}0.071 \\
0.094 \\
0.147 \\
0.030 \\
0.010 \\
0.021\end{array}$ & $\begin{array}{l}0.71 \\
0.72 \\
0.62 \\
0.68 \\
0.68 \\
0.68\end{array}$ & $\begin{array}{l}1.77 \\
3.03 \\
2.25\end{array}$ & $\begin{array}{l}1.06 \\
1.12 \\
1.08\end{array}$ \\
\hline
\end{tabular}


Table 3. Same as Table 2 but using ash-free dry weight ( $\mu$ gind.$^{-1}$ ). The present experiment was converted into dry weight using the Paffenhöfer (1976) size/ash-free dry weight relationship

\begin{tabular}{|c|c|c|c|c|c|c|}
\hline Source & Species & $T\left({ }^{\circ} \mathrm{C}\right)$ & a & $b$ & $Q_{10}$ & $Q_{1}$ \\
\hline Nival et al. $(1972)^{a}$ & $\begin{array}{l}\text { Copepods } \\
\text { Other zooplankton }\end{array}$ & $\begin{array}{l}15 \\
15\end{array}$ & $\begin{array}{l}0.002 \\
0.004\end{array}$ & $\begin{array}{l}0.84 \\
0.52\end{array}$ & & \\
\hline Mayzaud $(1973)^{a}$ & Meganyctiphanes norvegica & 13 & 0.361 & 0.45 & & \\
\hline Ikeda (1974) & Zooplankton & $\begin{array}{c}4-14 \\
11-17^{\mathrm{a}} \\
17-22 \\
25-28\end{array}$ & $\begin{array}{l}0.057 \\
0.127 \\
0.321 \\
0.481\end{array}$ & $\begin{array}{l}0.78 \\
0.76 \\
0.66 \\
0.60\end{array}$ & & \\
\hline Nival et al. $(1974)^{a}$ & Copepods & $13-23$ & 0.002 & 1.02 & 2.47 & 1.10 \\
\hline Vidal $(1980)^{\mathrm{a}}$ & Calanus pacificus & $\begin{array}{c}8 \\
12 \\
15.5\end{array}$ & $\begin{array}{l}0.009 \\
0.012 \\
0.015 \\
0.006 \\
0.005 \\
0.006\end{array}$ & $\begin{array}{l}0.83 \\
0.83 \\
0.82 \\
0.82 \\
0.82 \\
0.82\end{array}$ & $\begin{array}{l}1.75 \\
1.90 \\
1.82\end{array}$ & $\begin{array}{l}1.06 \\
1.07 \\
1.06\end{array}$ \\
\hline Present experiments & Oikopleura dioica & $\begin{array}{c}\mathrm{H} 15^{\circ} \mathrm{C} \\
\mathrm{L} 15^{\circ} \mathrm{C} \\
\text { No food } 15^{\circ} \mathrm{C} \\
\text { Anaesthetized } 15^{\circ} \mathrm{C} \\
\mathrm{H} 22^{\circ} \mathrm{C} \\
\mathrm{H}+\mathrm{L}+\text { No food } 15^{\circ} \mathrm{C} \\
\text { Pooled data }\end{array}$ & $\begin{array}{l}0.017 \\
0.016 \\
0.028 \\
0.008 \\
0.032 \\
0.020 \\
0.007\end{array}$ & $\begin{array}{l}0.76 \\
0.64 \\
0.59 \\
1.10 \\
0.93 \\
0.78 \\
0.74\end{array}$ & 1.99 & 1.07 \\
\hline
\end{tabular}

been calculated (Mayzaud 1973b, Conover 1978), and that this complicates inter-comparisons. For example, Gorsky et al. (1987) found $Q_{10}$ values of 1.77 and 3.03 in the ranges 15 to $20^{\circ} \mathrm{C}$ and 20 to $24^{\circ} \mathrm{C}$, respectively. The respiration $Q_{10}$ estimated for $O$. dioica is higher than those found by Broms \& Tisselius (2003) for filtration $\left(Q_{10}=1.78,10\right.$ to $\left.20^{\circ} \mathrm{C}\right)$ or for gut clearance $\left(Q_{10}=\right.$ $1.46,10-20^{\circ} \mathrm{C}$ López-Urrutia \& Acuña 1999) but is similar to those found by Sato et al. (2001) for house production $\left(Q_{10}=1.90\right.$ to $2.2,15$ to $\left.25^{\circ} \mathrm{C}\right)$. These results indicate that, at a higher temperature, respiration is relatively more enhanced than filtration and digestion, suggesting that growth efficiency should decrease.

At the same temperature, the weight specific respiration rate of appendicularians is significantly higher than in many other zooplankton species (Fig. 4). The Oikopleura dioica oxygen consumption measured in the present study is 2.85 times higher than for Euphausia pacifica (Ross 1982), 7 times higher than for the copepods and macroplankton (Nival et al. 1972), and 4 to 17 times higher than the rates reported by Ikeda (1974) for mixed zooplankton samples. Our results are in the range measured for Calanus pacificus (Vidal 1980) and for copepods (Nival et al. 1974) (1.14 and 1.46 times higher, respectively).

According to the literature, respiration has generally been measured on food-deprived animals in order to avoid the background respiration of living particles such as bacteria or algae (Mayzaud 1973a, Mayzaud \& Dallot 1973, Ivleva 1980, Kremer 1982, Ross 1982), and, only in a few cases, on feeding organisms (Milliou \& Moraitou-Apostolopoulou 1991, Thor 2003). The response of appendicularians to the different food conditions tested in this study is rather surprising. The respiration remained practically unchanged whatever the food condition including starvation. This result is in strong contradiction with the significant decrease of respiration observed by many authors on starved or food-limited species of copepods (Nival et al. 1972, Abou Debs 1984, Milliou \& Moraitou-Apostolopoulou 1991), salps (Cetta et al. 1986), ctenophores (Kremer 1982, Kremer et al. 1986) or pooled zooplankton species (Nival et al. 1972, Mayzaud 1973a, Ikeda 1977). Only in a few cases was the oxygen consumption shown to remain constant or to increase with decreasing food concentration (Mayzaud \& Dallot 1973 on Sagitta setosa).

Individual respiration reflects the sum of 3 main metabolic costs (Conover 1978, Vidal 1980): maintenance, motor activity including filtration, and digestion. Selander \& Tiselius (2003) have shown that the filtration activity of appendicularians is greatly stimulated by food deprivation. Thus, a higher respiration rate in starved appendicularians might be expected but this was not observed. One possible hypothetical and unverifiable explanation is that the expenses due 

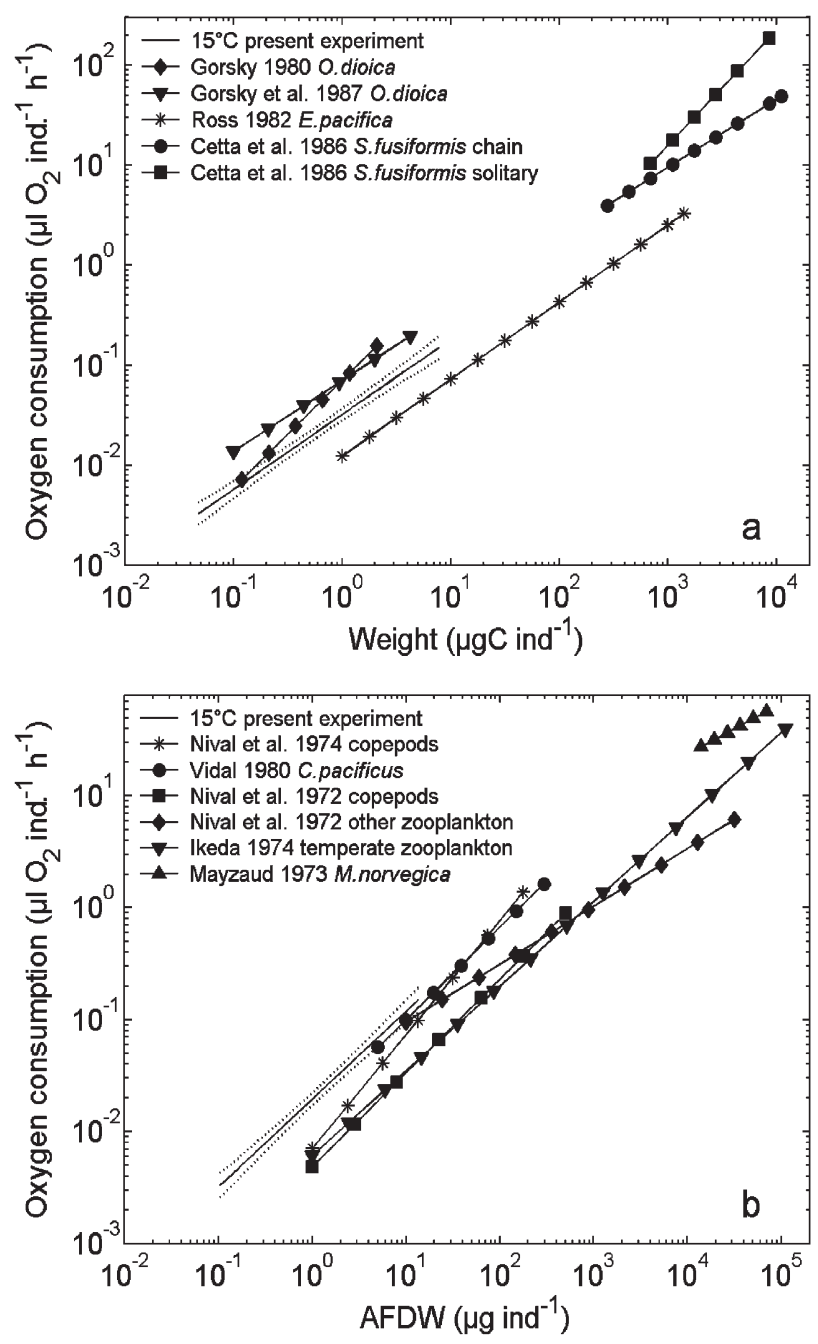

Fig. 4. Oxygen consumption of different zooplankton groups compared with Oikopleura dioica. These data were calculated for $15^{\circ} \mathrm{C}$ or studied in the same temperature range. (a) Relationship between organism carbon weight $\left(\mu \mathrm{g} \mathrm{C}\right.$ ind ${ }^{-1}$ ) and oxygen consumption $\left(\mathrm{\mu l} \mathrm{O}_{2}\right.$ ind. $\left.{ }^{-1} \mathrm{~h}^{-1}\right)$. Least-square regression (thick line), $95 \%$ confidence interval (dotted lines), of active $O$. dioica at $15^{\circ} \mathrm{C}$. Data is also shown for $O$. dioica at $15^{\circ} \mathrm{C}$ (Gorsky 1980, Gorsky et al. 1987), Euphausia pacifica (Ross 1982) and for Salpa fusiformis in chain and in solitary form (Cetta et al. 1986). (b) The relationship between organisms ash-free dry weight (AFDW $\mu \mathrm{g}$ ind. ${ }^{-1}$ ) and oxygen consumption $\left(\mu \mathrm{O}_{2}\right.$ ind.$^{-1} \mathrm{~h}^{-1}$ ). Least-square regression (thick line) and $95 \%$ confidence interval (dotted lines) for active $O$. dioica at $15^{\circ} \mathrm{C}$, data were calculated from size using the Paffenhöfer (1976) relationship. Copepod data are also shown from Nival et al. (1972, 1974), for pooled zooplankton (Nival et al. 1972, Ikeda 1974), for Meganyctiphanes norvegica (Mayzaud 1973), and for Calanus pacificus (Vidal 1980)

to filtration are offset by the reduction in digestion activity. Another hypothesis relies on the unusually high basal respiration recorded from Oikopleura dioica in this study. Basal respiration is amongst the most difficult to measure (Conover 1978), and very few data have been collected on zooplankton. Nevertheless, our results show that basal respiration of appendicularians, which is about $67 \%$ of total respiration, is higher than in salps (15 to $30 \%$; Trueman et al. 1984), copepods (20\%; Kiørboe et al. 1985) or ctenophores (22\%; Svetlichny et al. 2004). This difference, which could explain the higher respiration in appendicularians compared to other zooplankton species, can be related to the metabolic cost induced by the production of new houses, and the intense ciliary movement in spiracles and the digestive tract. Respiration due to filtration and digestion represents only $34 \%$ of the total respiration. Selander \& Tiselius (2003) showed that the effort required for filtration is related to the algal concentration with a maximum activity of 510 tail beats $\mathrm{min}^{-1}$ and with minimum activity of 380 tail beats $\mathrm{min}^{-1}$. Moreover if we apply the food concentrations of the present study to their relationship, the tail-beating frequency should range between 450 and 510 tail beats $\mathrm{min}^{-1}$. If one considers that the active respiration rate is directly proportional to the tail beating frequency and that respiration due to digestion is negligible, the increase in total respiration due to the motor activity in the lower concentrations should be $4 \%$, a value too small to be detected. In extreme cases shown by Selander \& Tiselius (2003) with algal concentrations ranging from 0 to $1300 \mu \mathrm{g} \mathrm{C}^{-1}$ we should observe a difference of only $10 \%$.

In contrast with other numerous zooplankton groups, appendicularians seem to lack regulatory mechanisms for respiration. This has some implications on the survival of Oikopleura dioica over long starvation periods. Based on the respiration rates measured in this study and on the $\mathrm{N}$ excretion rates given by Gorsky et al. (1987), the preliminary calculated O: $\mathrm{N}$ ratio range is low ( 7 to 10 ), suggesting a protein-based metabolism with no or low metabolic storage (Mayzaud \& Conover 1988). O. dioica had few or no dietary reserves (Gorsky 1987, Deibel 1998) and a high turnover rate; assuming a respiratory quotient of 0.87 (Mayzaud et al. 2005), the oxygen consumption rates measured for $O$. dioica ( $1 \mu \mathrm{g} \mathrm{C}$ weight) at 15 and $22^{\circ} \mathrm{C}$ correspond to carbon turnover rates of 41 and $74 \% \mathrm{~d}^{-1}$, respectively. These values are similar to those observed for salps $(31 \%$ average; Cetta et al. 1986), but are higher than those of crustaceans (10 to $15 \%$ on Euphausia pacifica, Ross $1982 ; 1.4$ to $23 \%$ on Oithona similis, Castellani et al. 2005). These turnover rates did not equal the total carbon turnover rate of appendicularians, as the house production, which represents an important part of the balance (130 to $290 \%$; Sato et al. 2001) was not considered in this study. Considering the case of exclusively protein-based metabolism, Mayzaud (1973a) concluded that, in the case of starvation, basal meta- 
bolism might be sustained by the body mass degradation. The rate of degradation would increase with the decrease of available metabolic substrate, although the respiratory rate remains constant as observed for appendicularians. Therefore, appendicularians cannot survive over long periods without food (15 h in our preliminary experiments, 48 h for Gorsky 1980), contrary to other zooplankton species such as Eucalanus bungii bungii which can be starved for $113 \mathrm{~d}, 49 \mathrm{~d}$ for Calanus plumchus (Ikeda 1974), 35 d for Calanus finmarchicus (Mayzaud 1976), and 18 d for Sagitta setosa (Mayzaud \& Dallot 1973; for more data see Ikeda 1974). According to Ikeda (1974), the time of zooplankton survival in starved conditions is dependent not only on the animal reserves but equally on its weight specific respiration rate. We have shown that the active and basal respiration rates in appendicularians are higher than in most zooplankton species. In the case of a long-term starvation period (over $8 \mathrm{~h}$ ), we have observed that appendicularians cease to produce houses. Animals then start to break down their oikoplastic cells layer as described by Fenaux \& Gorsky (1983) for O. longicauda, and finally resorb their digestive system (Fenaux \& Gorsky 1983, authors' pers. obs.), but not their gonads, which can mature rapidly in certain cases. These conditions of total starvation are unusual in the sea because appendicularians can feed upon submicronic particles (Gorsky et al. 1999, Fernández et al. 2004), including colloidal particles (Flood et al. 1992). They are also able to survive at very low particles concentrations (López-Urrutia et al. 2003) by increasing their filtration rate (Acuña \& Kiefer 2000, Selander \& Tiselius 2003). This leads to the assumption that their adaptive strategy is based on increasing their filtering rate in unfavourable conditions rather than on the regulation of their metabolism. This strategy may be considered as an adaptation to low food conditions but it does not allow survival during long periods of actual starvation.

Finally, among the 2 hypotheses considered in the models of López-Urrutia et al. (2003) and Touratier et al. (2003), the more realistic is that the respiration rate is independent of food concentration (López-Urrutia et al. 2003). These models should be further developed in order to test the adaptive strategies which allow successful development of appendicularians in all marine regimes, including extreme conditions.

Acknowledgments. We thank E. M. Thompson and J.-M. Bouquet (Sars International Center, Bergen, Norway) for the supply of fertilized appendicularian eggs, C. Troedsson for his help in the initial phase of this work, I. Palazzoli for the Coulter Counter measurements, F. Renaud for his contribution in oxygen data acquisition, P. Nival, S. Nival, P. Mayzaud and L. Stemmann for constructive discussions.

\section{LITERATURE CITED}

Abou Debs C (1984) Carbon and nitrogen budget of the calanoid copepod Temora stylifera: effect of the concentration and the composition of food. Mar Ecol Prog Ser 15:213-223

Acuña JL, Kiefer M (2000) Functional response of the appendicularian Oikopleura dioica. Limnol Oceanogr 45: $608-618$

Alldredge AL (2004) The contribution of discarded appendicularian houses to the flux of particulate organic carbon from oceanic surface waters. In: Gorsky G, Youngbluth MJ, Deibel D (eds) Response of marine ecosystems to global change: ecological impact of appendicularians. GB Scientific Publisher, Paris, p 309-326

Barnes B, Barnes M (1969) Seasonal changes in the acutely determined oxygen consumption and effect of temperature for three common cirripedes, Balanus balanoides (L.), B. balanus (L.) and Chthamalus stellatus (Poli). J Exp Mar Biol Ecol 4:36-50

Biggs DC (1977) Respiration and amonium excretion by open ocean gelatinous zooplankton. Limnol Oceanogr 22: $108-117$

Broms F, Tisselius P (2003) Effects of temperature and body size on the clearance rate of Oikopleura dioica. J Plankton Res 25:573-577

Castellani C, Robinson C, Smith T, Lampitt RS (2005) Temperature affects respiration rate of Oithona similis. Mar Ecol Prog Ser 285:129-135

Cetta CM, Madin LP, Kremer P (1986) Respiration and excretion by oceanic salps. Mar Biol 91:529-537

Conover RJ (1960) The feeding behavior and respiration of some marine planktonic Crustacea. Biol Bull (Woods Hole) 119:399-415

Conover RJ (1978) Transformation of organic matter. In: Kinne O (ed) Marine ecology: a comprehensive, integrated treatise on life in oceans and coastal waters. IV. Dynamics. Wiley Interscience, Chichester, p 221-499

Deibel D (1998) Feeding and metabolism of Appendicularia. In: Bone Q (ed) The biology of pelagic tunicates. Oxford University Press, Oxford, p 139-149

Fenaux R, Gorsky G (1983) Cycle vital et croissance de l'appendiculaire Oikopleura longicauda (Vogt), 1854. Ann de Inst Oceanogr 59:107-116

Fenaux R, Gorsky G (1985) Nouvelle technique d'élevage des appendiculaires. Rapp Comm Int Mer Médit 29:291-292

Fernández D, López-Urrutia A, Fernández A, Acuña JL, Harris R (2004) Retention efficiency of 0.2 to $6 \mu \mathrm{m}$ particles by the appendicularians Oikopleura dioica and Fritillaria borealis. Mar Ecol Prog Ser 266:89-101

Flood PR, Deibel D (1998) The appendicularian house. In: Bone Q (ed) The biology of pelagic tunicates. Oxford University Press, Oxford, p 105-124

Flood PR, Deibel D, Morris C (1992) Filtration of colloidal melanin from seawater by planktonic tunicates. Nature 355:630-632

Gorsky G (1980) Optimisation des cultures d'appendiculaires. Approche du métabolisme de Oikopleura dioica. Thèse $3^{\text {e }}$ cycle, Université $P$ et M Curie, Paris

Gorsky G (1987) Aspects de l'ecophysiologie de l'appendiculaire Oikopleura dioica Fol, 1872 (Chordata: Tunicata). Thèse d'état, Université $P$ et $M$ Curie, Paris

Gorsky G, Fenaux R (1998) The role of Appendicularia in marine food webs. In: Bone Q (ed) The biology of pelagic tunicates. Oxford University Press, Oxford, p 161-169

Gorsky G, Palazzoli I, Fenaux R (1984) Premières données sur la respiration des appendiculaires (tuniciers pélagiques). CR Hebd Seances Acad Sci Paris 298:531-534 
Gorsky G, Palazzoli I, Fenaux R (1987) Influence of temperature on oxygen uptake and ammonia and phosphate excretion, in relation to body size and weight, in Oikopleura dioica (Appendicularia). Mar Biol 94:191-201

Gorsky G, Chrétiennot-Dinnet MJ, Blanchot J, Palazzoli I (1999) Picoplankton and nanoplankton aggregation by appendicularians: fecal pellet contents of Megalocercus huxleyi in equatorial Pacific. J Geophys Res C 104:3381-3390

Hemmingsen AM (1960) Energy metabolism as related to body size and respiration surfaces, and its evolution. Rep Steno Mem Hosp Nord Insulinlab 9:1-110

Hopcroft RR, Roff JC (1995) Zooplankton growth rates: extraordinary production by the larvacean Oikopleura dioica in tropical waters. J Plankton Res 17:205-220

Hopcroft RR, Roff JC, Bouman HA (1998) Zooplankton growth rates: the larvaceans Appendicularia, Fritillaria and Oikopleura in tropical waters. J Plankton Res 20:539-555

Ikeda T (1974) Nutritional ecology of marine zooplankton. Mem Fac Fish Hokkaido Univ 22:1-97

Ikeda T (1977) The effect of the laboratory conditions on the extrapolation of experimental measurements to the ecology of marine zooplankton. IV. Changes in respiration and excretion rates of boreal zooplankton species maintained under fed and starved conditions. Mar Biol 41:241-252

Ivleva IV (1980) The dependence of crustacean respiration rate on body mass and habitat temperature. Int Rev Gesamten Hydrobiol 65:1-47

King KR, Hollibaugh JT, Azam F (1980) Predator-prey interactions between the larvacean Oikopleura dioica and bacterioplankton in enclosed water columns. Mar Biol 56:49-57

Kiørboe T, Møhlenberg F, Hamburger K (1985) Bioenergetics of the planktonic copepod Acartia tonsa: relation between feeding, egg production and respiration, and composition of specific dynamic action. Mar Ecol Prog Ser 26:85-97

Kremer P (1982) Effect of food availability on the metabolism of the ctenophore Mnemiopsis mccradyi. Mar Biol 71: 149-156

Kremer P, Canino MF, Gilmer RW (1986) Metabolism of epipelagic tropical ctenophores. Mar Biol 90:403-412

Leonard JBK, Summers AP, Koob TJ (1999) Metabolic rate of embryonic little skate, Raja erinacea (Chondrichthyes: Batoidea): the cost of active pumping. J Exp Zool 283:13-18

López-Urrutia A, Acuña JL (1999) Gut throughput dynamics in the appendicularian Oikopleura dioica. Mar Ecol Prog Ser 191:195-205. Erratum in Mar Ecol Prog Ser 193:310 (2000)

López-Urrutia A, Acuña JL, Irigoien X, Harris R (2003) Food limitation and growth in temperate epipelagic appendicularians (Tunicata). Mar Ecol Prog Ser 252:143-157

Maar M, Nielsen TG, Gooding S, Tonnesson K and 5 others (2004) Trophodynamic function of copepods, appendicularians and protozooplankton in the late summer zooplankton community in the Skagerrak. Mar Biol 144: 917-934

Mayzaud P (1973a) Respiration and nitrogen excretion of zooplankton. II. Studies of the metabolic characteristics of starved animals. Mar Biol 21:19-28

Mayzaud P (1973b) Respiration et Excrétion azotée du zooplancton. III. Etude de l'influence des variations thermiques. Ann Inst Oceanogr 49:113-122

Mayzaud P (1976) Respiration and nitrogen excretion of zooplankton. IV. The influence of starvation on the metabolism and the biochemical composition of some species. Mar Biol 37:47-58

Mayzaud P, Conover RJ (1988) O:N atomic ratio as a tool to describe zooplankton metabolism. Mar Ecol Prog Ser 45: 289-302

Mayzaud P, Dallot S (1973) Respiration et excrétion azotée du zooplancton. I. Etude des niveaux métaboliques de quelques espèces de Méditerranée occidentale. Mar Biol 19:307-314

Mayzaud P, Boutoute M, Gasparini SP, Mousseau L, Lefevre D (2005) Respiration in marine zooplankton - the other side of the coin: $\mathrm{CO}_{2}$ production. Limnol Oceanogr 50:291-298

Milliou H, Moraitou-Apostolopoulou M (1991) Variations of respiratory rate of Tisbe holothuriae Humes (Copepoda, Harpacticoida) in relation to temperature, salinity and food type. Comp Biochem Phys A 100:169-174

Moloney CL, Field JG (1989) General allometric equations for rates of nutrients uptake, ingestion, and respiration in plankton organisms. Limnol Oceanogr 37:1290-1299

Nival P, Nival S, Palazzoli I (1972) Données sur la respiration de différents organismes communs dans le plancton de Villefranche-sur-Mer. Mar Biol 17:63-76

Nival P, Mallara G, Charra R, Palazolli I, Nival S (1974) Etude de la respiration et de l'excrétion de quelques copépodes planctoniques (crustacea) dans la zone de remontée d'eau profonde des côtes Marocaines. J Exp Mar Biol Ecol 15: 231-260

Paffenhöfer GA (1976). On the biology of Appendicularia of the southeastern North Sea. In: Persoone G, Jasper E (eds) Proc 10th Eur Symp Mar Biol, Vol 2. Universal Press, Wetteren, p 437-455

Purcell JE, Sturdevant MV, Galt CP (2004) A review of appendicularians as prey of invertebrate and fish predators. In: Gorsky G, Youngbluth MJ, Deibel D (eds) Response of marine ecosystems to global change: ecological impact of appendicularians. GB Scientific Publisher, Paris, p 359-435

Ross RM (1982) Energetics of Euphausia pacifica. I. Effects of body carbon and nitrogen and temperature on measured and predicted production. Mar Biol 68:1-13

Sato R, Tanaka Y, Ishimaru T (2001) House production by Oikopleura dioica (Tunicata, Appendicularia) under laboratory conditions. J Plankton Res 23:415-423

Selander E, Tiselius P (2003) Effects of food concentration on the behaviour of Oikopleura dioica. Mar Biol 142:263-270

Svetlichny LS, Abolmasova GI, Hubareva ES, Finenko GA, Bat L, Kideys AE (2004) Respiration rates of Beroe ovata in the Black Sea. Mar Biol 145:585-594

Thor P (2003) Elevated respiration rates of the neritic copepod Acartia tonsa during recovery from starvation. J Exp Mar Biol Ecol 283:133-143

Touratier F, Legendre L, Vézina A (1999) Model of copepod growth influenced by the food carbon:nitrogen ratio and concentration, under the hypothesis of strict homeostasis. J Plankton Res 21:1111-1132

Touratier F, Carlotti F, Gorsky G (2003) Individual growth model for the appendicularian Oikopleura dioica. Mar Ecol Prog Ser 248:141-163

Trueman ER, Bone Q, Braconnot JC (1984) Oxygen consumption in swimming salps (Tunicata: Thaliacea). J Exp Biol 110:323-327

Uye S, Ichino S (1995) Seasonal variations in abundance, size composition, biomass and production rate of Oikopleura dioica (Fol) (Tunicata: Appendicularia) in a temperate eutrophic inlet. J Exp Mar Biol Ecol 189:1-11

Vidal J (1980) Physioecology of zooplankton. III. Effects of phytoplankton concentration, temperature, and body size on the metabolic rate of Calanus pacificus. Mar Biol 56: 195-202

Youngbluth MJ, Kremer P, Bailey TG, Jacoby CA (1988) Chemical composition, metabolic rates and feeding behavior of the midwater ctenophore Bathocyroe fosteri. Mar Biol 98:87-94 